\title{
THE WATER RELATIONS AND IRRIGATION REQUIREMENTS OF SUGAR GANE (SACGHARUM OFFICINARUM): A REVIEW
}

\author{
By M. K. V. GARR †, $\ddagger$ and J. W. KNOX \\ Cranfield University, Cranfield, Bedfordshire, MK43 OAL, UK
}

(Accepted 3 September 2010)

\begin{abstract}
SUMMARY
The results of research on the water relations and irrigation needs of sugar cane are collated and summarized in an attempt to link fundamental studies on crop physiology to irrigation practices. Background information on the centres of production of sugar cane is followed by reviews of (1) crop development, including roots; (2) plant water relations; (3) crop water requirements; (4) water productivity; (5) irrigation systems and (6) irrigation scheduling. The majority of the recent research published in the international literature has been conducted in Australia and southern Africa. Leaf/stem extension is a more sensitive indicator of the onset of water stress than stomatal conductance or photosynthesis. Possible mechanisms by which cultivars differ in their responses to drought have been described. Roots extend in depth at rates of 5-18 $\mathrm{mm} \mathrm{d}^{-1}$ reaching maximum depths of $>4 \mathrm{~m}$ in $c a .300 \mathrm{~d}$ providing there are no physical restrictions. The Penman-Monteith equation and the USWB Class A pan both give good estimates of reference crop evapotranspiration (ETo). The corresponding values for the crop coefficient $(\mathrm{Kc})$ are 0.4 (initial stage), 1.25 (peak season) and 0.75 (drying off phase). On an annual basis, the total water-use (ETc) is in the range $1100-1800 \mathrm{~mm}$, with peak daily rates of $6-15 \mathrm{~mm} \mathrm{~d}^{-1}$. There is a linear relationship between cane/sucrose yields and actual evapotranspiration (ETc) over the season, with slopes of about 100 (cane) and 13 (sugar) $\mathrm{kg}$ (ha mm) ${ }^{-1}$ (but variable). Water stress during tillering need not result in a loss in yield because of compensatory growth on re-watering. Water can be withheld prior to harvest for periods of time up to the equivalent of twice the depth of available water in the root zone. As alternatives to traditional furrow irrigation, drag-line sprinklers and centre pivots have several advantages, such as allowing the application of small quantities of water at frequent intervals. Drip irrigation should only be contemplated when there are well-organized management systems in place. Methods for scheduling irrigation are summarized and the reasons for their limited uptake considered. In conclusion, the 'drivers for change', including the need for improved environmental protection, influencing technology choice if irrigated sugar cane production is to be sustainable are summarized.
\end{abstract}

\section{INTRODUCTION}

Sugar cane is grown in diverse areas of the world ranging from warm temperate regions to the humid tropics. In many places, water management is a major component of the production system. In some countries (e.g. Swaziland) irrigation is essential for profitable commercial production while in others (e.g. South Africa) it is supplementary to variable rainfall. Much research has been reported on the water relations and irrigation requirements of sugar cane, most recently from Australia and South Africa. This paper attempts to synthesize this research from an independent perspective and

$\dagger$ Emeritus Professor

‡Corresponding author. mikecarr@cwms.org.uk; Contact address: Pear Tree Cottage, Frog Lane, Ilmington, Shipston on Stour, Warwickshire, GV36 4LQ, UK 
to do this in practically useful ways. It follows the format of previous reviews in this series, notably those on coffee (Carr, 2001) and banana (Carr, 2009). It begins with a summary of the origin and centres of production, followed by reviews of the effects of water stress on crop development processes (including roots), plant water relations, crop water requirements, water productivity, irrigation systems and irrigation scheduling. The paper concludes with a section on the 'drivers for change' in the sugar cane industry including the need to use water and energy more efficiently, and to minimize environmental degradation in cost effective ways.

Various aspects of this topic have previously been reviewed by Finkel (1983), Yates (1984), Jones et al. (1990), Inman-Bamber and Smith (2005) and Martin et al. (2007).

\section{CENTRES OF PRODUGTION}

Saccharum officinarum (the so-called Noble Cane because of its fine thick stem) is believed to have originated in the islands of the South Pacific, probably New Guinea $\left(2-10^{\circ} \mathrm{S}\right)$ having evolved through human selection from strains of two wild species S. robustum and S. spontaneum and hybridization with S. sinense (Bull and Glasziou, 1976; Jones et al., 1990; Julien et al., 1989; Purseglove, 1972; Simmonds, 1998). Because of its natural sweetness, it has been grown for chewing since ancient times in the Pacific and Southeast Asia. The production of sugar from sugar cane began in India, followed by China, Persia (Iran), Egypt and Spain, and elsewhere around the Mediterranean. In the seventeenth century the first plantations were established in the West Indies, and the resultant need for labour, particularly for harvesting, led to sugar cane's links with the slave trade.

Most of the commerce between Europe and the sugar regions of the West that followed was subsequently based on the outward shipment of slaves and the homeward carriage of sugar, molasses and rum (Hobhouse, 1985; Purseglove, 1972). Molasses, the dark brown viscous liquid residue left behind after the centrifugal process has ended and no more sucrose can be extracted, is one of the most important byproducts (contains 50\% fermentable sugars) from the manufacture of cane sugar. It is used as a raw material in industry. Rum is produced by the fermentation of molasses, followed by distillation. Other products include industrial ethyl alcohol (ethanol), which is manufactured from molasses, and bagasse, the fibrous residue left after the extraction of juice from the cane (used for fuel in the sugar factory, as well as in various manufacturing processes). The pith from the bagasse is used as a stockfeed. Not much of the plant is wasted.

Up to the end of the nineteenth century, only a few clones of S. officinarum had been used to establish the major portion of the world's sugar cane industry (Bull and Glasziou, 1976). Almost all the commercial cultivars grown today are interspecific hybrids of Saccharum species specially bred during the twentieth century, mainly for disease and pest resistance (Purseglove, 1972).

Sugar cane, a C4 carbon fixation pathway species, is adapted to a range of tropical and subtropical climates, and is grown from southern Spain $\left(37^{\circ} \mathbf{N}\right)$ to South Africa $\left(30^{\circ} \mathrm{S}\right)$, and from sea level up to $1700 \mathrm{~m}$ near the equator. The optimum air temperature 
for growth is in the range $28-30^{\circ} \mathrm{C}$ whilst the base temperature varies with the development stage from 12 to $19^{\circ} \mathrm{C}$ (Liu et al., 1998). Sugar cane can be grown on a diverse range of soils (Jones et al., 1990) ${ }^{1}$. In 2007, the top 10 countries in terms of value and total annual production were Brazil, India (by far the two biggest), China, Thailand, Mexico, Pakistan, Australia, Colombia, USA and Guatemala (FAO, 2009). In 2007, the total harvested area of sugar cane in the world was about 22.7 million ha (FAO, 2009) of which about 10.2 million ha (45\%) were irrigated (Portmann et al., 2008).

In Brazil alone, the planted area of sugar cane is 8 million ha producing 650 million $\mathrm{t}$ of cane (fresh weight) in 2008 of which about $45 \%$ is used for ethanol production. Only about $1 \%$ of the total area is currently irrigated, but this is liable to increase (Laclau and Laclau, 2009). In Australia, about $60 \%$ of the sugar produced depends on irrigation to some extent. Regional water supplies there are becoming increasingly limited, and there is rising pressure on growers to improve their on-farm water management practices (Inman-Bamber, 2004). In South Africa about $40 \%$ of the crop depends on irrigation (Inman-Bamber and Smith, 2005).

\section{GROP DEVELOPMENT}

Sugar cane is a perennial crop in which flowering is undesirable. The crop is produced from stalk cuttings called setts. Each node has an axillary bud and a band of root primordia, and is capable of giving rise to a new plant. The 'germination' of setts requires moist soil surrounding the stem. The developing bud is initially dependent on the sett for nutrients and water, but it develops its own root system after about three weeks. Once the new plant is established, roots arise from underground nodes and the axillary buds at these nodes give rise to tillers (Bull and Glasziou, 1976). As the crop develops there is an overproduction of tillers (stalks), with peak numbers (up to $25 \mathrm{~m}^{-2}$ ) attained three to five months from planting, but $50 \%$ of these can die (as a result of shading) before a stable stalk population is reached after about nine months. Tiller senescence begins when about $70 \%$ of incident radiation is intercepted by the leaf canopy (Inman-Bamber, 1994).

The effects of water stress on crop development processes are considered here in the following sequence: leaf canopy, yield accumulation (grand growth), ripening/dryingoff, flowering and ratoons, ending with a summary of factors influencing the development of root systems.

\section{Leaf canopy}

In a review, Inman-Bamber and Smith (2005) summarized the stages of vegetative growth and the influence of water stress as follows.

- Leaf initiation continues even when leaf appearance is impeded by dry soil.

\footnotetext{
${ }^{1}$ The reader is referred to a review paper by Sumner (1997), focusing on sugar cane, which describes the chemical and physical degradation of soils resulting from organic matter depletion, crust formation, acidification, salinization and sodification. Available strategies for amelioration and case studies with successful outcomes are discussed.
} 
- Leaf extension is sensitive to water stress declining, for example, from $40 \mathrm{~mm} \mathrm{~d}^{-1}$, when the leaf water potential at midday is $-0.5 \mathrm{MPa}$, to zero when the leaf water potential falls to $-1.3 \mathrm{MPa}$ (cys NCo376 and N11).

- Stem extension rates are more sensitive to water stress than leaf extension rates.

- Compensatory growth can occur when water stress is relieved; e.g. the relative leaf extension rate (the ratio of actual leaf extension rate to that of the control well-watered treatment) can exceed 1.0 within three days of rain.

Subsequently, Smit and Singels (2006) reported the results of a study in South Africa $\left(29^{\circ} 42^{\prime} \mathrm{S} ; 31^{\circ} 02^{\prime} \mathrm{E}\right.$; alt. $\left.96 \mathrm{~m}\right)$ of the effects of controlled water stress on leaf canopy development. They found that leaf senescence was affected most by drought, followed by leaf appearance and then tiller senescence.

There were differences in response between cultivars. For example, cv. NCo376 was able to maintain canopy development processes, particularly slower rates of tiller and leaf senescence, for longer than $c v$. N22 as the soil dried, at least initially. At the same time, $c v$. NCo376 was also able to maintain stomatal conductances and leaf water potentials at higher levels than $c v$. N22 (a cultivar known commercially as being drought sensitive).

Similarly, in a preliminary pot experiment, cultivar N11 appeared to be better adapted to water stress than $c v$. NCo376 since it could adjust its leaf area more rapidly and tended to elongate at a slightly lower leaf water potential than $c v$. NCo376. This concurred with the results of field trials in South Africa in which $c v$. N11 produced higher sucrose yields than $c v$. NCo376 in dry conditions, but not under irrigation (Inman-Bamber and De Jager, 1986).

\section{Field accumulation/grand growth}

In sugar cane, sucrose is stored in the stalk parenchyma cells. Accumulation is a continuous process throughout the life of the plant. In commercial varieties, sucrose concentration increases from 10\% (dry mass) in young plants to about $50 \%$ as they mature (Julien et al., 1989). In commercial production, sucrose yield is commonly expressed as the product of the fresh weight of stalks (cane) and sucrose concentration $(\%)$.

For well-adapted cultivars grown in Australia and South Africa, partitioning of plant biomass to above ground organs is similar for a wide range of climatic conditions, with the trash component (dead leaves and stalks) varying most (Inman-Bamber et al., 2002). For crops yielding $>60 \mathrm{t} \mathrm{ha}^{-1}$ dry mass (green biomass = biomass less the trash), the stalk component reached a maximum value of about 0.85 regardless of cultivar or extremes of water regime. Seasonal and age effects on whole stalk sucrose content are due to varying proportions of young segments (low sucrose content) and older segments (high). From a comparison of high and low sucrose content clones, Inman-Bamber et al. (2009) concluded that there is little direct genetic control on the maximum amount of sucrose that can accumulate in the stalk. Rather, differences between cultivars reside more in the morphology of the plant and responses to ripening stimuli such as mild water stress. 
In Ayr, Queensland (19 $32^{\prime} \mathrm{S}, 147^{\circ} 25^{\prime} \mathrm{E}$; altitude $15 \mathrm{~m}$ asl), Inman-Bamber (2004) reported the responses of two cultivars (Q96 and Q124), both with well-developed leaf canopies, to increasing soil water deficits. Yield-forming processes responded in the following sequence as stress levels increased. Under high evaporating conditions (ETc up to $7.5 \mathrm{~mm} \mathrm{~d}^{-1}$ ):

- Leaf and stalk extension rates declined when the measured soil water deficit (SWD) was $c a .60 \mathrm{~mm}$, reaching very low levels at a SWD of $130 \mathrm{~mm}$;

- The number of green leaves per stalk was reduced at a SWD of $80 \mathrm{~mm}$;

- Biomass accumulation declined at a SWD of $130 \mathrm{~mm}$; and

- Sucrose yield declined at a SWD of $150 \mathrm{~mm}$.

For comparison, the total available water content in the root zone was $>230 \mathrm{~mm}$.

\section{Ripening/drying-off}

This relative sensitivity of expansive growth to water stress compared with photosynthesis means that sucrose is diverted from growth to storage in the stem, a phenomenon exploited by the practice of 'drying-off' before harvest (Inman-Bamber and Smith, 2005).

In irrigated sugar cane production, water is usually withheld prior to harvest (i) to dry the field and (ii) to raise the sucrose concentration of the cane. Because past research had given conflicting results on the optimum duration of the drying-off period, Robertson and Donaldson (1998) undertook a detailed analysis of pooled data from 37 experiments (mainly $c v$. NCo376) conducted in Southern Africa. In only 22\% of the drying-off treatments (total 174) was there a significant increase in the yield of sucrose, averaging $8 \%$ (maximum 15\%), over the well-watered control treatment. This increase occurred when the reduction in cane yield (dry mass) was no greater than about $10 \%$. In $61 \%$ of the drying-off treatments there was a significant increase in the sucrose concentration (\% fresh mass), as a result of an increase in the soluble solids together with dehydration. However, sucrose yields only increase if water stress reduces stalk biomass by less than $4 \%$ (Donaldson and Bezuidenhout, 2000). Using this information, the CANEGRO model (ICSM, 2008) was used to simulate the optimum drying-off period (for crops harvested annually) for different soil types, locations and month of harvest in South Africa. A set of tables was produced, with adjustments depending on anticipated rainfall. As a general rule, this equated to the time it would take for the cumulative total evaporation from a pan to equal twice the water holding capacity of the soil (depth not specified) in which the crop was grown.

The results of a one year duration experiment in Swaziland with a ratoon crop (cv. NCo376), confirmed that there was no reduction in the yield of cane if water was withheld for either seven or ten weeks. This was equivalent to cumulative evaporation prior to harvest 1.5 and three times the total available water in the root zone $(80 \mathrm{~mm})$, respectively. There was a minor improvement in cane quality through an increase in sucrose content (Ellis and Lankford, 1990). 


\section{Flowering}

Although nearly all sugar cane species and varieties flower ('arrow'), producing large panicles of tiny flowers and fertile seed, selection programmes are biased against flowering. Most varieties will not flower at day lengths longer than about $13 \mathrm{~h}$ or shorter than $12 \mathrm{~h}$ (Bull and Glasziou, 1976). Water stress can delay flowering if it occurs before flower inductive conditions arise. The effect of flowering on yield is complex and dependent on several factors and is not always deleterious (Julien et al., 1989).

\section{Ratoons}

A ratoon refers to the regrowth of a cane crop after harvesting. New shoots develop from the axillary buds of the stubble piece. In Swaziland, Ellis and Lankford (1990) found that, providing the plant crop was irrigated immediately after harvest, the ratoon crop did not need to be irrigated again until the onset of rapid shoot elongation. The plant crop is usually followed by up to eight ratoons, sometimes more depending on the rate of yield decline.

In tropical Queensland, Australia $\left(18.7^{\circ} \mathrm{S}, 146.2^{\circ} \mathrm{E}\right.$; altitude $150 \mathrm{~m}$ asl) ratoon crops accumulated biomass faster than plant crops (both irrigated) during the first 100 days due to higher stalk number, faster canopy development and more radiation interception (Robertson et al., 1996). These differences became negligible after 220 days because maximum radiation use efficiency was larger in the plant crop $(1.72 \mathrm{~g}$ $\mathrm{MJ}^{-1}$, excluding trash) than in the first ratoon $\left(1.59 \mathrm{~g} \mathrm{MJ}^{-1}\right)$. Biomass accumulation reached a plateau (53-58 $\mathrm{t} \mathrm{ha}^{-1}$ ) after 300 days from planting/ratooning, 140 days before harvest. This plateau was associated with the loss of live millable stalks, and not with a cessation of growth of individual stalks. Over the 15-month season the crops intercepted about $70 \%$ of the incident radiation. This study emphasized the point that maximizing early radiation interception does not necessarily lead to higher yields.

\section{Summary: crop development}

1. Moist soil is needed to establish a sett.

2. Stem/leaf extension is particularly sensitive to water stress.

3. An excess of tillers is produced, some die due to shading.

4. Maximizing early radiation interception is not necessary.

5. Compensatory growth occurs when dry soil is rewetted.

6. Water can be withheld prior to harvest without loss of yield.

7. For a ratoon crop, water needs to be applied immediately after harvest.

8. No further water is needed until rapid stem elongation begins.

\section{Roots}

An excellent review of the growth and function of the sugar cane root system was published by Smith et al. (2005). It focused on physical (soil compaction, high water tables) and genetic (differences between cultivars) factors influencing the capacity of roots to access water and nutrients particularly at depth, the likelihood that root water status may influence assimilation through its effect on stomatal conductance 
(by chemical signals), and the possibility that yield improvements by breeding may have resulted from a focus on above ground components of yield at the expense of roots. They concluded that, because the underground carbon budget for sugar cane is poorly understood, more research is justified in order to improve further the access and utilization of resources by roots.

Factors affecting the growth and function of the roots of sugar cane, including their sensitivity to soil compaction and water logging, had previously been reviewed in detail by Humbert (1968). Cultivars differ in the size of their root system and in the shoot to root ratios, which increase with increasing productivity. The maximum depths of rooting, as listed, varied with soil type, ranging from 0.9 to $2.2 \mathrm{~m}$.

The root system can be divided into three types of roots: superficial, buttress and rope. Superficial roots are thin and branched with numerous rootlets with root hairs; they exploit the upper layers of the soil. Buttress roots provide anchorage whilst rope roots grow down to considerable depths (Julien et al., 1989). But, as Smith et al. (2005) pointed out, it is unclear how common rope systems are in modern cultivars. Roots of sugar cane are not perennial. Each new stem produces its own root system from its basal nodes. The new root system cannot be formed until the soil around the base of the new stem has been moistened (Yates, 1984).

Sett roots grow at a rate of up to $24 \mathrm{~mm} \mathrm{~d}^{-1}$. These stop elongating when they are $150-250 \mathrm{~mm}$ in length and quickly produce a much-branched network of thin sub-roots, but these die within eight weeks of planting as roots originating from basal nodes of developing shoots take over. Primary shoot roots grow faster at up to $75 \mathrm{~mm}$ $\mathrm{d}^{-1}$ (Glover, 1967 cited by Jones et al., 1990; Thompson, 1976), and reach depths of $1.0 \mathrm{~m}$ in about $120 \mathrm{~d}, 1.5 \mathrm{~m}$ in $160 \mathrm{~d}$ and $2.0 \mathrm{~m}$ in $190 \mathrm{~d}$ (Wood and Wood, 1967 cited by Jones et al., 1990). Maximum rooting depths for sugar cane in South Africa of between $0.8 \mathrm{~m}$ and $4.0 \mathrm{~m}$ were reported by Thompson (1976) depending largely on soil type. Based on observations made in a rhizotron, Van Antwerpen (1999) recorded roots (cv. NCo376) descending in depth at average rates of $22 \mathrm{~mm} \mathrm{~d}^{-1}$ in sandy soils and reaching maximum depths of about $2 \mathrm{~m}$ in 87 days. Rates of root penetration were less in a sandy clay loam taking 176 days to reach the same depth. Smith et al. (2005) confirmed that root density (biomass and length) declines exponentially with depth with roots sometimes reaching depths $>6 \mathrm{~m}$.

A detailed study of the development and distribution of roots of a plant crop $(c v$. RB72454) grown on a Xanthic Ferrasol soil with and without supplementary irrigation in Piracicaba, Brazil $\left(22^{\circ} 42^{\prime} \mathrm{S}, 47^{\circ} 33^{\prime} \mathrm{W}\right.$; alt. $\left.570 \mathrm{~m}\right)$ was reported recently by Laclau and Laclau (2009). For the first four months after planting the 'root front' extended at a rate of about $5 \mathrm{~mm} \mathrm{~d}^{-1}$, and afterwards until harvest (322 days after planting) at about $18 \mathrm{~mm} \mathrm{~d}^{-1}$, almost independent of the water regime. Roots reached maximum depths of $4.25 \mathrm{~m}$ with irrigation and $4.70 \mathrm{~m}$ when rain-fed. About $50 \%$ of the total number of root intersects were below a depth of $1 \mathrm{~m}$ in both treatments, as observed on a trench wall.

The root systems of ratoon crops are less well developed than those of the plant crop, the roots of which can remain active for a considerable period after harvest (up to 60 days) as the new root system develops on the developing shoot of the ratoon 
crop. Partial survival of the root system of the plant crop appears to provide protection against drought during the early stages of growth of the ratoon crop (Smith et al., 2005).

\section{Summary: roots}

1. After planting in wet soil, the sett produces short-lived, thin roots.

2. Their function is taken over by roots that develop from basal nodes of developing shoots.

3. Each stem produces its own root system.

4. The soil needs to be moist close to the stem for roots to develop.

5. Shoot roots extend in depth at rates varying between 5 and $22 \mathrm{~mm} \mathrm{~d}^{-1}$, reaching depths of $1 \mathrm{~m}$ in about 140-150 days, $2 \mathrm{~m}$ in 190-200 days and $4 \mathrm{~m}$ in 300-310 days.

6. Providing that there are no physical restrictions (e.g. compact soil, water-logging) roots can be expected to reach depths of $4 \mathrm{~m}$.

7. Irrigation has a relatively small effect on root depth and distribution.

8. After harvest, the root system of the plant crop remains active for up to 60 days.

9. A new root system develops from the developing stem of the ratoon crop.

\section{PLANT WATER RELATIONS}

Stomata are more abundant (about twice as many) on the lower (abaxial) surface of the leaf lamina than on the upper (adaxial) surface (Julien et al., 1989). In India, stomata on the adaxial surface of leaves of cultivars subjected to water stress were observed to be more sensitive (closed earlier) than those on the abaxial surface (Venkataramana et al., 1986).

In a field study in Hawaii $\left(21^{\circ} \mathrm{N}, 158^{\circ} \mathrm{W}\right.$; altitude $100 \mathrm{~m}$ asl), Meinzer and Grantz (1989) measured simultaneously the stomatal conductances of single leaves (steady state porometer; $c v$. H65-7052) and transpiration from a developing canopy (Bowen ratio method). Because the aerodynamic resistances were large, transpiration was not under direct stomatal control (uncoupled) and, as a result, small changes in stomatal openings had little effect initially on transpiration.

Some cultivars maintain strict control over stomatal conductance during drought, so controlling water loss and maintaining green leaf area (Bull and Glasziou, 1976). With one drought resistant Hawaiian cultivar (H69-8235), Inman-Bamber and Smith (2005) described how the stomata closed rapidly as the soil dried $(\Psi \mathrm{m}$ declined from 0 to $-40 \mathrm{kPa}$ ). The stomata of the same cultivar were also sensitive to small changes in leaf water potential. Its reputation for drought resistance was considered to be a result in part of its capacity to conserve water through early stomatal closure. Similarly, the reputation that $c v$. N12 has in South Africa for drought resistance/avoidance was also thought to be a result of early stomatal closure.

In Mauritius, Roberts et al. (1990) measured diurnal changes in stomatal conductances with a portable infra red gas analyser. The maximum values recorded were around $400 \mu$ mols m ${ }^{-2} \mathrm{~s}^{-1}$ (measured across both leaf surfaces) in well-irrigated cane but less than this on days when the saturation deficit of the air (SD) was high 
(ca. 1.7 kPa). Conductances were very low at leaf water potentials of $-1.7 \mathrm{MPa}$. The sensitivity of stomatal conductance to changes in leaf water potential was illustrated under both clear sky and cloudy conditions with full stomatal closure occurring at about - 1.8 MPa (Turner, 1990).

In the same series of drip irrigation experiments in Mauritius, leaf extension rate was found to be more sensitive to water stress than either stomatal conductance or photosynthesis. Daytime depressions of leaf extension rates were even observed in wellirrigated treatments during the middle of the day when evaporation rates were high. Recovery from water stress was always rapid (within a few days of water being applied) with rates reaching levels in excess of those in the well-watered control treatments (Roberts et al., 1990).

In South Africa, Inman-Bamber and De Jager (1986) were able to relate observed changes in growth processes to the decline in the midday leaf water potential $(\Psi \mathrm{L})$ as the soil dried:

- Stem/leaf extension rate is reduced and the youngest unfurled leaves begin to roll at $\Psi \mathrm{L}=-0.8 \mathrm{MPa}$.

- Stomatal conductance starts to fall at $\Psi \mathrm{L}=-0.8$ to $-1.0 \mathrm{MPa}$.

- Stem extension ceases and stomatal conductance reaches a minimum at $\Psi \mathrm{L}=$ -1.3 to $-1.7 \mathrm{MPa}$.

- The youngest unfurled leaves became fully rolled at $\Psi \mathrm{L}=-2.0 \mathrm{MPa}$.

Osmotic regulation has been observed in Hawaii by Koehler et al. (1982) when, during drought, the concentrations of potassium and reducing sugars in the leaf blade increased (cv. H62-4271), but only after stem elongation rates had declined. Similarly, in Mauritius, an osmotic adjustment at full turgor of about 0.4-0.6 MPa between drip-irrigated and rain-fed sugar cane (cv. R570) was recorded by Roberts et al. (1990). After repeated periods of water stress, osmoregulation has also been observed in pot grown plants, but to a lesser extent (Inman-Bamber and De Jager, 1986).

\section{Summary: plant water relations}

1. When the aerodynamic resistance is relatively large, changes in stomatal opening do not have an immediate, direct effect on transpiration.

2. Stomatal conductance is sensitive to changes in leaf water potential (possible role of root signals?).

3. Some (limited) evidence of sensitivity of stomata to dry air ( $\mathrm{SD} \geq 1.7 \mathrm{kPa}$ ).

4. Conductance is very low at leaf water potentials of $-1.7 \mathrm{MPa}$.

5. Leaf extension rate (and leaf rolling) is a more sensitive indicator of water stress than stomatal conductance or photosynthesis.

6. Drought resistance is associated with early stomatal closure.

7. Growth processes linked to decline in midday leaf water potential as soil dries.

8. Some (limited) evidence that osmotic regulation can occur. 
Probably the first attempt to quantify the actual water use of sugar cane based on rational physical processes was that reported by Cowan and Innes (1956) in Jamaica. They related monthly water use by a full canopy of cane (ETc) measured with 24 drainage lysimeters to the Penman equation (1948 and 1951 versions) estimate of evaporation from an open water surface (Eo) using standard meteorological data. The value of the ETc/Eo ratio (f) so obtained was 0.57-0.58. They also found that leaf elongation rates were linearly related to the accumulated soil water deficit.

In South Africa $\left(29^{\circ} 26^{\prime} \mathrm{S}, 31^{\circ} 12^{\prime} \mathrm{E}\right)$, Thompson and Boyce (1967) measured daily ETc using four hydraulic lysimeters. They confirmed the large effects advection could have along the Natal coast on ETc rates on individual days. As a result the Penman equation (1963 version) estimate of potential ETc was sometimes less than the measured value. The most consistent relationship was between measured ETc and USWB Class A evaporation pan data with a mean ratio of 1.0. Later, Thompson and Boyce (1971), in a comparison of large and small lysimeters, observed that ETc rates declined by about 30\% after crops lodged (plant and ratoons), an effect that lasted 2-3 months. In a follow-up study, Thompson and Boyce (1972) compared four models of estimating ETc using standard weather data together with estimates of the aerodynamic and canopy (stomatal) resistances, values of which were derived from field measurements. The Penman-Monteith equation (1965 version) gave the best (i.e. closest to weekly lysimeter measurements) estimate of ETc. Actual ETc rates fell below potential rates when the soil water deficit exceeded $50 \mathrm{~mm}$. Because of the complexity of the Penman-Monteith model, and the close relationship between ETc and Epan (effectively 1:1), USWB Class A pans were recommended for use by irrigation water managers. This confirmed advice given earlier by Thompson et al. (1963).

Subsequently, Thompson (1976) reviewed the research undertaken in South Africa, but in the context of related work reported from Argentina, Australia, Hawaii and Mauritius. Water-use was considered under five stages of crop development: bare soil, partial crop cover, complete crop cover, lodged crop and during the drying-off period before harvest. Under bare soil conditions, the effects of weeds, trash, frequency of wetting and soil type were considered at two sites in South Africa, and total water use estimated for each situation. Similarly ETc figures were tabulated for different degrees of crop cover. The ETc/Epan ratio reached 1.0 when the crop cover (viewed vertically) exceeded $80-90 \%$.When/if the crop lodged, the ratio fell to about 0.7 for up to three months. Water use during the drying-off period fell below potential ETc rates as irrigation water was withheld. Based on neutron probe measurements, Thompson (1976) considered it to be realistic to assume that $50 \%$ of the total available water $(\Psi$ soil between -0.01 and $-1.5 \mathrm{MPa})$ in the root zone (maximum depth) was 'freely available' to the plant. During the drying-off phase, the actual rate of water use was then assumed to decline at a progressive rate until all the available water had been used.

Total water use varies considerably depending in part on the duration of the crop (Thompson, 1976). On an annual basis, it can range from 1100 to $1800 \mathrm{~mm}$ depending 
on the location (based on lysimeter data from different parts of the world). Similarly, peak rates of water use for sugar cane between 6 and $15 \mathrm{~mm} \mathrm{~d}^{-1}$ have been reported internationally. There were indications that the ETc/Epan ratio was: (i) less than 1.0 in the winter months and (ii) lower in the ratoon crop than the plant crop.

In a detailed study conducted at two sites (Kalamia Estate, northeast Australia $19^{\circ} 6^{\prime} \mathrm{S} 14^{\circ} 4^{\prime} \mathrm{E}$, and Simunye Estate, Swaziland $26^{\circ} 12^{\prime} \mathrm{S}, 31^{\circ} 55^{\prime} \mathrm{E}$; altitude $250 \mathrm{~m}$ asl), Inman-Bamber and McGlinchey (2003) measured daily ETc rates using the Bowen ratio energy balance method. They confirmed that a realistic mean $\mathrm{Kc}$ value (ETc/ETo) during the initial stage of crop development was 0.4 , and during the mid-season 1.25 (when $>80 \%$ of the incoming radiation was intercepted by the canopy). For a crop that continued to be well watered $\mathrm{Kc}=1.25$ was considered to be appropriate until harvest but, in order to impose water stress ahead of harvest, a Kc value of 0.7 may be desirable. (For this stage Allen et al. (1998) suggest a Kc value of 0.75). Actual ETc rates in mid-season averaged $5.48 \pm 0.13 \mathrm{~mm} \mathrm{~d}^{-1}$ in Australia and $5.19 \pm 0.26 \mathrm{~mm} \mathrm{~d}^{-1}$ in Swaziland. The corresponding ETo (reference crop) values were $4.44 \pm 0.07 \mathrm{~mm} \mathrm{~d}^{-1}$ and $3.98 \pm 0.16 \mathrm{~mm} \mathrm{~d}^{-1}$.

An attempt was made by Chabot et al. (2005) to measure transpiration of sugar cane in the field (Gharb plain, Morocco, $34.67^{\circ} \mathrm{N}, 8.75^{\circ} \mathrm{W}$ ), using the sap flow technique. Based on measurements on 14 individual stems they found that estimates of mid-season ETc (ca. $8 \mathrm{~mm} \mathrm{~d}^{-1}$ ) were more than $30 \%$ above those predicted from the PenmanMonteith equation (ETo) using the appropriate mid-season crop factor (ETc = 1.23ETo). Although $8 \mathrm{~mm} \mathrm{~d}^{-1}$ is not an unrealistic value for August in that location, the authors believed that the sap flow technique was an inappropriate method for determining transpiration rates from a heterogeneous canopy like that of sugar cane because of uncertainties in the methodology.

A novel way of measuring actual water use of sugar cane was described by Omary and Izuno (1995) in the Everglades, south Florida, USA. They monitored daily changes in the height of the water table over a two-year period (plant crop and first ratoon). Diurnal changes in ET rates were discernible. Minimum daily values occurred in December through to February $\left(0.7-1.5 \mathrm{~mm} \mathrm{~d}^{-1}\right)$, and maximum rates during June to September $\left(4.5-4.6 \mathrm{~mm} \mathrm{~d}^{-1}\right)$. The total annual ET averaged $1060 \mathrm{~mm}$. Crop coefficients were derived for the Penman Eo estimate (1948 version), with a peak mid-season value of 1.27 in September.

\section{Summary: crop water requirements}

1. On an annual basis, the water-use of sugar cane is in the range $1100-1800 \mathrm{~mm}$, depending on location.

2. Peak daily ETc rates of $6-15 \mathrm{~mm} \mathrm{~d}^{-1}$ have been reported.

3. Different ways of calculating ETo, Eo or Epan will result in different Kc (or equivalent) values.

4. The Penman-Monteith equation gives the best estimate of ETo.

5. Evaporation from a USWB Class A pan can give a good approximation of this estimate of ETo $(1: 1)$. 
6. The generally accepted values for the crop coefficient $(\mathrm{Kc}=\mathrm{ETc} / \mathrm{ETo})$ are as follows: initial stage $=0.4$ (depends on wetting interval); peak season $=1.25$ (when crop cover $>80 \%$ ); drying-off phase (if practised) $=0.75$ (otherwise 1.25 continues).

7. Lodging can reduce ETc by $30 \%$.

\section{WATER PRODUCTIVITY}

In Hawaii, Chang et al. (1963) were amongst the first people to recognize the relationship that existed between the ratios of actual to potential yield of sugar cane and actual to potential evapotranspiration, and to develop a general equation to predict yield.

Later, in Natal, South Africa $\left(c a .30^{\circ} \mathrm{S}\right)$, the responses of sugar cane (cv. NCo376) to a range of supplementary irrigation treatments on two soil types, sand and clay, were compared (Thompson et al., 1967). The yield response to irrigation water applied was similar at both sites averaging $84 \mathrm{~kg}$ (ha $\mathrm{mm})^{-1}$. Rain-fed crops grown on the sand extracted water from depths of $2 \mathrm{~m}$, whilst those on the clay to only $1.2 \mathrm{~m}$, reflecting the relative differences in the depth of rooting on the two soils. On both soils there was a linear relationship between the rate of increase in height of the cane and actual daily water use. In three follow-up experiments on the same two soil types, Thompson and De Robillard (1968) described a linear relationship between cane yield and 'effective' water application (rain plus irrigation, range $750-1800 \mathrm{~mm}, n=14$ ) with a slope of $120 \mathrm{~kg}(\text { ha mm})^{-1}$.

Data from irrigation experiments conducted across the world (Australia, Hawaii, Mauritius as well as South Africa) were collated by Thompson (1976) and significant linear relations between the yield of cane (Y, range $=<100$ to $>300 \mathrm{t} \mathrm{ha}^{-1}$, fresh weight) and total water use (ET, range $=<1000$ to $>3000 \mathrm{~mm})$ were derived:

$$
\mathrm{Y}( \pm 15.1)=0.0969 \mathrm{ET}-2.4(\mathrm{r}=0.95 ; \mathrm{n}=91)
$$

For sucrose, the corresponding relationship was:

$$
\mathrm{Y}( \pm 3.43)=0.0135 \mathrm{ET}-1.32(r=0.75 ; \mathrm{n}=85)
$$

Based on their international experience, Yates and Taylor (1986) urged caution when using water use efficiency values alone to justify investment in supplementary irrigation in areas receiving $1200 \mathrm{~mm}$ or more rainfall. Other factors play a role in determining yield responses to water, including the depth of rooting, soil type, climatic conditions and standards of management. An analysis of commercial yields (unirrigated) in upland Kenya, for both smallholders and estates gave water use efficiencies (based on estimated values of actual ETc) of only $50-60 \mathrm{~kg}$ (ha mm) ${ }^{-1}$, less than the generally accepted realistic commercial value $\left(100 \mathrm{~kg}(\mathrm{ha} \mathrm{mm})^{-1}\right)$ (Bull and Glasziou, 1976; Julien et al., 1989). An example was also given of how advection of hot, dry air on crop water use (in semi-arid Somalia) can reduce water use efficiencies.

In the FAO Irrigation and Drainage Paper 'Yield response to water' (Doorenbos and Kassam, 1979), typical 'water use efficiencies' for cane yield (80\% moisture content) 
were presented as 50-80 kg (ha mm) ${ }^{-1}$ and for sucrose (dry) 6-10 kg (ha mm $)^{-1}$. These are both of the same orders of magnitude as those summarized here.

Several researchers have looked at the effect of water stress at different stages of growth on yield. In semi-arid northeast Australia $\left(20^{\circ} \mathrm{S}, 147^{\circ} \mathrm{E}\right)$, Robertson et al. (1999) reported (for cvs Q96 and Q1 17) that deficits imposed during tillering, although having large effects on leaf area, tillering and biomass production at the time, had no effect on final yield, due in part to compensatory growth when watering began again. By contrast, deficits imposed when the canopy was well established (leaf area index >2) reduced biomass and sugar production. Unfortunately, the levels of stress imposed were not well defined so it is difficult to extrapolate these detailed findings to other situations.

In a five-year field study in Texas $\left(27^{\circ} \mathrm{N}, 98^{\circ} \mathrm{W}\right)$, Wiedenfeld (2000) found that withholding (supplementary) irrigation during one of four individual six-week periods during the grand-growth stage resulted in only relatively small reductions in cane or sugar yields, depending on the level of stress. The maximum yield loss, with no rain or irrigation for six weeks in mid-summer, was predicted to be 8-15\% for cane yield and $12-19 \%$ for sugar. Yield responses to nitrogen fertilizer were not affected by the irrigation treatments.

In Swaziland, Ellis and Lankford (1990) suggested, on the basis of the results of a one-year trial and previous work in Zimbabwe (Ellis et al., 1985), that water could be saved by scheduling irrigation using an ETc/Epan ratio of 0.8 rather than 1.0 during the period of stem elongation, without loss of yield. This treatment, when combined with no irrigation prior to rapid stem elongation and a drying-off period prior to harvest resulted in a water saving compared with local practices of about $20 \%$.

Doorenbos and Kassam (1979) identified four growth stages: establishment, vegetative, yield formation and ripening. The corresponding values for the 'yield response factor' $(\mathrm{Ky})$, which is a measure of the relative sensitivity to drought or response to irrigation, were given as $0.75,0.75,0.5$ and 0.1 , respectively. For the whole growing period Ky had a value of 1.2 (values of 1.0 or above imply sensitivity to water stress), which indicates a relative yield loss greater than any corresponding reduction in evapotranspiration. It is not explained how these values were derived and, following this review, it is not possible to verify them or to suggest alternatives.

\section{Summary: water productivity}

Despite difficulties in extrapolation, it is possible to come to the following broad conclusions from the information presented.

1. There is a linear relationship between cane yield and actual evapotranspiration (ETc).

2. The slope of this relationship (benchmark) is of the order of $100 \mathrm{~kg}$ (ha mm) ${ }^{-1}$, but variable.

3. The corresponding value for sucrose is about $13 \mathrm{~kg}(\mathrm{ha} \mathrm{mm})^{-1}$.

4. Water stress during tillering need not reduce final yields because of compensatory growth on re-watering. 
5. Water stress during 'grand growth' does not necessarily lead to a large (>15\%) loss in yield.

6. Water can be withheld prior to harvest for periods equivalent to up to twice the total depth of available water in the root zone.

7. Opportunities exist to reduce the depth of irrigation water applied without loss in yield, depending on soil type, at all growth stages.

8. It is not possible to reconcile the FAO figures for the 'yield response factor' with this information.

\section{IRRIGATION SYSTEMS}

The choice of method for irrigating sugar cane depends on many factors that are site and context specific. The merits and limitations of different systems (not crop specific) have been described by Jones et al. (1990) and Kay (1990) and for sugar cane cultivation by James (2004). This review is restricted to those irrigation systems evaluated on sugar cane and particularly the drivers forcing growers to switch technology to improve system performance and efficiency.

For many crops, including sugar cane, the capacity of a system to apply water uniformly and efficiently is a major factor influencing the agronomic and economic viability of production (Qureshi et al., 2001). But switching from traditional gravity-fed schemes to modern pressurized systems does not necessarily lead to better irrigation performance unless the management skills and experience of the irrigator allow the equipment to be used effectively. For sugar cane, methods that are widely used include surface (furrow) based systems, overhead (sprinklers, centre-pivots and rain-guns) and micro (drip) irrigation.

\section{Furrow irrigation}

Furrow irrigation was favoured in many early sugar cane developments, due to its low capital costs, suitability for land with gentle slopes and operational simplicity (Holden, 1998). However, rising costs for energy (pumping) and labour (furrow is labour intensive) has led to existing schemes in Swaziland being replaced with overhead or micro irrigation systems (Merry, 2003). There are also increasing concerns regarding the environmental impacts of large drainage flows and deep percolation losses that can occur from furrow-irrigated fields (Mhlanga et al., 2006). For example, in north Queensland, Australia, the long-term use of furrow irrigation is reported to be contributing to a rise in the water table and an increase in salinity (Tilley and Chapman, 1999).

In Burdekin, Australia, Qureshi et al. (2001) used a bio-economic modelling approach to assess the viability of switching from furrow to either centre pivot or drip irrigation. They concluded that furrow irrigation remains the most attractive option when water charges are low. Only when volumetric water charging is considered as a policy option does centre pivot irrigation become the preferred option. 


\section{Overhead irrigation}

The main overhead systems used for sugar cane are semi-permanent sprinklers and centre pivots, and to a much lesser extent high pressure rain guns.

Sprinklers - drag-line: In drag-line irrigation a rotary impact sprinkler is attached to a riser and connected to a quick release valve via a flexible hose. Compared with conventional sprinkler systems with portable pipes, there are fewer pipe moves (as only the hose and sprinkler are moved) with consequential labour savings, for a modest increase in capital cost (installation of underground laterals). They are robust and flexible and can be designed to cope with most soil types, small and odd-shaped fields, obstructions and even different crops (ratoons) within one field. They are simple to operate and highly visible, making faults (blocked sprinklers) easy to identify and remedy (Merry, 2003). For these reasons, they have proved popular especially in southern Africa (Zadrazil, 1990). However, the system is susceptible to wind drift (particularly when the cane is young) as the sprinklers are mounted on tall $(2.5 \mathrm{~m})$ risers to cope with irrigating a full cane canopy.

Centre-pivots: In a number of regions including Africa, Brazil and Australia there has been a steady uptake in the use of centre-pivots in sugar cane. The reasons include low running costs (compared to furrow), lower labour and energy requirements, ease of operation and the potential to achieve high application uniformities even under windy conditions (Teeluck, 1997).

Although originally adopted by the large-scale commercial growers, centre-pivots have also proved popular with small-scale farmers in organized associations in Swaziland. The conversion from surface irrigated rectangular fields can create problems dealing with field corners that then require a separate irrigation system, usually dragline sprinklers or drip. Centre-pivots can cope with undulating land and awkward field boundaries (e.g. drainage ditches), but a disadvantage is the relatively high capital cost whilst fields generally need to be at least 40 ha to make investment worthwhile.

Rain guns: Due to their robustness and versatility, high pressure, high volume sprinklers (rain guns) were widely used from the 1950s to irrigate sugar cane in Mauritius, Zambia, South Africa, Swaziland and Australia. However, the large water droplets can cause damage to young sugar cane and create capping problems on sensitive soils. Since 1990, however, rising energy costs coupled with increasing demands for improved water application and crop uniformity have resulted in these systems being replaced by drag-lines and centre-pivots (Teeluck, 1997).

\section{Drip irrigation}

With drip irrigation small quantities of water are applied at frequent intervals directly to the soil. In Hawaii (USA), drip irrigation has been the principal method used to irrigate sugar cane since the 1970s (Koehler et al., 1982), whilst it has been evaluated elsewhere in the world. For example, Pollok et al. (1990) described the installation and operation of a fully-automated, commercial 40 ha drip irrigation scheme in Swaziland. Although this pioneering initiative was considered to be a success, such a sophisticated 
system, it was judged, should only be contemplated where there are well-organized management systems in place. Malfunctions of equipment and components require constant monitoring and rectification as consequential crop losses are large. When well managed, drip irrigation systems have the potential to achieve high $(>90 \%)$ application efficiencies (Tilley and Chapman, 1999), whilst there are also potential water savings when compared with the losses associated with surface or overhead methods. Research has concentrated on design issues that relate to the siting and spacing of the lateral pipes and drippers, quantifying the amount of water to apply relative to other irrigation methods, and the amelioration of problem soils.

In a detailed experiment in Mauritius $\left(20^{\circ} \mathrm{S}, 57^{\prime} \mathrm{E}\right.$; altitude $70 \mathrm{~m}$ asl) reported by Batchelor et al. (1990), a treatment with buried (0.2 m) sub-row drip lines out-yielded an alternate inter-row drip line treatment over three years (plant crop plus two ratoons, cv. Saipan). Applying water during tillering at 0.5ETc resulted in similar yields to those obtained from applying more water at that time (1.0 or $1.5 \mathrm{ETC})$. Despite a large number of supporting measurements, it is difficult to extrapolate the results, which are not easy to interpret, beyond the locality where these experiments were conducted. More roots grew in the inter-row areas when a drip irrigation emitter was present. Drip irrigation also altered the relative distribution of roots vertically compared with a rain-fed crop (Soopramanien and Batchelor 1987, also described by Gregory, 1990).

On a poorly structured saline/sodic soil in Swaziland $\left(26^{\circ} \mathrm{S}, 32^{\circ} \mathrm{E}\right.$; altitude $\left.200 \mathrm{~m}\right)$, drip irrigation was compared with furrow irrigation to see if yields and the number of ratoons could be increased (Dodsworth et al., 1990). In the plant crop, drip irrigation gave a small $(7.5 \%)$ but non-significant yield benefit, but there was no advantage in the first or second ratoon crops. Despite operational problems, there were significant improvements each year in water-use efficiencies with drip irrigation (cane fresh weight, average 108 cf. $93 \mathrm{~kg}$ (ha $\left.\mathrm{mm})^{-1} ;+16 \%\right)$. Previously, Nixon and Workman (1987) had described the results of a field observation trial in which drip irrigation was compared with furrow irrigation on a similar poorly draining saline/sodic soil. Again, there was no benefit from drip irrigation except in the plant crop and the first ratoon. Indeed, in later ratoons, there was a negative yield response as the soil structure deteriorated further.

Following a cost-benefit analysis of seven different irrigation options, a subsurface drip system replaced ageing dragline sprinklers on a large commercial estate in Swaziland (Merry, 2003). A post-investment audit confirmed that there was a resultant $15 \%$ sucrose yield increase and a water-saving of $22 \%$ compared to the sprinkler system. Although these increases were above those originally envisaged, there is a problem in distinguishing the water saving due to better management from that due to the use of drip irrigation. Whether reported savings will persist once the drip system is no longer a closely monitored novelty remains to be seen.

In Mauritius, Ng Kee Kwong et al. (1999) showed how nitrogen fertilizer inputs could be reduced with drip irrigation (fertigation). Similarly, a study in Australia found that increased crop yields and sugar contents were possible, with a $25 \%$ reduction in nitrogen input relative to industry standards (Dart et al., 2000). Part of this gain arises from adjustments to nitrogen management to minimize the loss of nitrogen in wet 
periods, compared to other systems. However, high installation costs and problems associated with rodents and low water quality causing iron deposits in the laterals remain major barriers to the adoption of drip irrigation.

\section{IRRIGATION SGHEDULING}

Irrigation scheduling is the process of deciding when to irrigate and how much water to apply. The objective is to maintain optimum soil water conditions for growth in order to meet yield and quality targets with the minimum amount of water.

In the introduction to a paper describing the results of a survey of sugar cane irrigators in South Africa, Olivier and Singels (2004) explained how irrigation schedules can be defined as fixed (amount and cycle are kept constant for the entire growing season), semi-fixed (amount and cycle are changed a few times to accommodate rainfall and significant seasonal and crop age induced changes in water demand) or flexible (amount and timing are changed daily or weekly according to a calculated water balance based on recent crop and weather conditions).

Although many approaches have been promoted over the years for sugar cane (and other crops), it remains the case that only a minority of farmers use an objective (scientific) method of scheduling irrigation, and most still rely solely on their judgment based on intuition and/or crop appearance.

Visible symptoms of water stress include the following:

- The lamina of the upper leaves curl inward reducing the exposed leaf area.

- Young tillers roll their leaves before those on older stems.

- Senescence of the lower leaves begins.

\section{Irrigation method constraints}

In the four major irrigation areas in South Africa surveyed by Olivier and Singels (2004) scheduling practices were found to be highly dependent on the irrigation method being used. Drag-line systems were mainly operated on a semi-fixed schedule, due to labour constraints and design limitations, with allowance being made for rainfall and seasonal effects (winter and summer) and to a lesser extent crop age. By contrast, centre pivots and drip systems were mainly operated on a flexible schedule, with direct measurements of the soil water content (using a neutron probe) being the preferred method of assessment. Water budgeting using a water balance model was perceived as being 'too much trouble' in part due to lack of availability (at that time) of appropriate crop coefficient values. It was recommended that attempts should be made to persuade users of drag-line systems to change from fixed to semi-fixed scheduling, and users of centre pivots and drip systems to switch to flexible schedules. By so doing, it was estimated that the water-use efficiency of 18000 ha of irrigated sugar cane in South Africa could be improved. Although based on a relatively small sample size (40), these are interesting findings that are probably typical of many other areas of the world. This is perhaps due in part to the fact that for many growers scheduling is perceived to be unnecessary since it simply reinforces their existing knowledge. 
Olivier and Singels (2004) concluded from their study that the main barriers to the uptake of objective irrigation scheduling techniques in South Africa were (i) the complexity of the technology and the difficulty of applying it in practice on a farm and (ii) the perception that accurate scheduling provides little benefit.

\section{Leaf/stem extension}

In theory, it is possible to exploit the sensitivity of leaf extension to water stress to schedule irrigation of sugar cane. In South Africa, Inman-Bamber (1995) monitored diurnal changes in extension rates of the youngest visible leaf under different degrees of water stress. At low stress levels leaf extension rates were above $2 \mathrm{~mm} \mathrm{~h}^{-1}$ throughout the day, reaching 3-4 $\mathrm{mm} \mathrm{h}^{-1}$ by early evening. Under moderate stress, daytime extension was minimal and was exceeded by night time growth. Under severe stress, daytime extension was zero or negative (shrinkage), and at night it was reduced considerably. Recovery was very rapid (within a few days) on rewetting of the soil.

In Australia, relative shoot extension rate (RSER) is actually recommended as a criterion for judging when to irrigate $(\mathrm{RSER}<0.5)$, but farmers rarely have a control, well-watered treatment for comparison (Inman-Bamber and Smith, 2005). It may be possible, particularly under conditions of low evaporative demand, to reduce the critical RSER value from 0.5 to 0.3 without loss of yield. If water is limiting, it was suggested that irrigation could be delayed until leaf senescence began (Inman-Bamber, 2004).

Shoot extension rate (SER) or leaf extension rate (LER) alone is confounded with temperature effects, although an attempt to allow for this, by developing an index based on a comparison of early morning and daytime LERs, has been proposed (Inman-Bamber and Spillman, 2002).

Nevertheless, the rate of stem elongation and final internode lengths are convenient ways of assessing the effects of drought stress and, when compared with well-watered plants, provide a record of the timing, length and severity of a drought.

\section{'Simple' scheduling aids}

To address the problem of complexity, attempts have been made to develop 'simple' scheduling aids. For example, a device based on the water balance approach was promoted in South Africa for sugar cane growers by George (1988). Using long-term average evaporation data, and a measure of crop cover, together with an estimate of the allowable soil water deficit, it provided a visual indication, using coloured pegs placed in a 'pegboard', of when individual fields next needed to be irrigated.

Again with the same aim of simplicity, Torres (1998) described how, in Colombia, a suitably calibrated cylindrical plastic bucket $(0.3 \mathrm{~m} \times 0.4 \mathrm{~m}$ deep $)$ could be used to schedule irrigation of sugar cane. Based on a simple water balance, with a specified allowable depletion of the available water, it served as a visual aid of when to irrigate and how much water to apply. Its cheapness and simplicity made it appropriate for use by smallholders. 


\section{Tensiometers}

At another level of complexity, Bell et al. (1990) used an array of tensiometers in Mauritius for characterizing the soil water status beneath a drip-irrigated row crop. This provided a means of describing numerically the soil water potential distribution within a given volume of soil to be used by designers, researchers and managers of commercial plantations. It is not known if this approach has been applied in the ways suggested, but Hodnett et al. (1990) compared a method of scheduling irrigation based on this concept (using 'index' tensiometers) with the water balance method with some success.

Again with drip-irrigated sugar cane, Wiedenfeld (2004) compared four different methods of scheduling over three successive seasons in South Texas. Two were based on a water balance approach (pan evaporation and ETo-Penman-Monteith), and two on tensiometers (automatic and manual). All four methods were judged to be effective, although automatic tensiometers were found to be unreliable, with each prescribing similar quantities of water. The two water balance methods required crop coefficients appropriate to the location.

\section{Simulation models}

In an excellent review, Lisson et al. (2005) compared and contrasted the two main dynamic sugar cane simulation models, APSIM-Sugar cane and CANEGRO, and highlighted the role that modelling can/could play in the management of sugar cane production systems. This included: irrigation scheduling, optimizing the allocation of limited water supplies and assessing water storage options. Full details of the scientific basis of CANEGRO can be found on the web through ICSM (2008). More recently, Singels et al. (2010) proposed ways in which the water uptake component of the model could be improved.

\section{Irrigation scheduling services}

In South Africa, Singels and Smith (2006) described an irrigation scheduling service consisting of a web-based simulation model, (CANESIM) (see http://sasex.sasa.org.za/irricane/index.htm) that estimates the recent, current and future water balance, crop status and yield from field information and real time weather data. The system automatically generates and distributes simple, user specific, irrigation advice by a 'short message service' direct to farmers' cellular phones. An initial evaluation of the service on a small-scale sugar cane sprinkler irrigation scheme in South Africa indicated that, by following this advice, large reductions in water applied (33\%) and deep drainage (64\%) were possible. This was the result of reduced irrigation when the crop was young and during the winter months. Reliable feedback from the farmers was necessary for the service to be truly effective.

Recently, a web-based irrigation management service has been introduced in Queensland, Australia. Known as WaterSense, it is designed to assist growers who practice supplementary irrigation in areas where rainfall is variable, where water abstractions are at risk from restrictions and whose sugar cane fields are at different 
stages of development. It provides 'real time' advice on how to minimize yield losses when water is limited for individual fields (Haines et al., 2010; Inman-Bamber et al., 2008). Data from a network of automatic weather stations are used to calculate reference crop evapotranspiration whilst the APSIM-Sugar cane model simulates canopy development and soil water processes. An irrigation schedule is derived and accessed on a dedicated web page on a centrally located server that stores the database for participating growers.

\section{Conclusions}

Robertson et al. (1997) used a systems modelling approach to evaluate the opportunities that existed for improving the use of limited water by sugar cane farmers with case studies in Australia and South Africa. The importance of trying to ensure that the maximum quantity of water (rain and irrigation) is stored in the root zone was emphasized, together with the problems of managing variability in the field. The paper questioned the widespread use of a common value for the water use efficiency since it presupposes that it is relatively stable across production systems and environments (the APSIM-Sugar cane model suggested that it could vary from 50 to $150 \mathrm{~kg}$ (ha mm$)^{-1}$ ). The authors agreed that concepts such as effective rainfall and water-use efficiency still have a useful role to play as benchmarks against which to judge performance.

Many approaches to irrigation scheduling have been proposed to suit all levels of complexity, but few are widely used by irrigators of sugar cane. This will probably remain the case until the availability and cost of water becomes a real constraint. Useful practical bulletins on the irrigation of sugar cane have been published amongst others in South Africa (SASA, 1977) and in Australia (Holden, 1998).

\section{Drivers for change}

For many row crops, including sugar cane, the adoption of modern water-saving irrigation technologies is often cited as key to increasing water-use efficiency while maintaining current levels of production (Green et al., 1996). However, new technology requires greater capital investment, so irrigators are often reluctant to adopt new systems unless they can be convinced of the likely benefits. Where water costs are low, sugar cane growers have little incentive to switch technology to improve efficiency unless there are other externalities that might influence their ability to maximize net crop return. But rising energy, labour and water costs, the need to increase water productivity, less water available for abstraction due to expansion of cropped areas, increasing competition for limited resources, climate change risks (Knox et al., 2010) and demands for greater environmental protection are now the driving forces influencing technology choice in irrigated sugar cane production. In this context, better scheduling may prove to be a useful adaptation strategy.

The complexity of justifying a new investment in irrigation in areas where irrigation is supplementary to variable rainfall was demonstrated by Inman-Bamber et al. (1999). Basing their analysis on two case studies in Queensland, Australia, they compared measured yield responses to irrigation with simulated values using the APSIM-Sugar 
cane model. They then predicted the likely benefits in cash terms of an investment in different irrigation systems for a range of soils and scheduling options over a sequence of years. A positive return on an investment in supplementary irrigation was by no means a foregone conclusion despite favourable yield responses. Irrigation application efficiency was, for example, an important determinant of profitability.

\section{GONGLUSIONS}

For irrigation of sugar cane to be sustainable, the issues of concern that still needed to be addressed by the sugar industry (in Australia) were highlighted by Meyer (1997). Of overriding importance was drainage management for effluent control (excess water, salts, agrochemicals and nutrients), the need to maximize water productivity and to learn from history.

By contrast, in the conclusion to his review paper, Thompson (1976) argued that 'the degree of sophistication of irrigated sugar cane farming. . . is such that little will be gained from further research into the water requirements of the crop in the immediate future'. Thirty-five years later how justified was that statement?

Based on this review, progress of generic importance since 1976 appears to have been made in the following areas:

1. The sequential responses to drought have been quantified in terms of changes in leaf water potential.

2. Mechanisms responsible for drought tolerance are better understood.

3. Factors influencing the partitioning of dry matter and sucrose within the plant are better understood.

4. Factors influencing root growth rates and distribution and soil water availability, are better understood.

5. Ways of assessing crop water requirements, including realistic values of the crop coefficient, have been ratified.

6. Opportunities to save water by withholding irrigation at different growth stages have been identified.

7. Irrigation systems have been developed that allow water to be applied at the right time with improved precision (but at a cost).

8. New ways of scheduling irrigation have been developed and promoted but little evidence is yet available regarding levels of uptake.

How much of this knowledge has led to improvements in water management and increases in water productivity is not known. Probably not enough! The 'drivers of change' may not allow this state of affairs to continue much longer.

Acknowledgements. The helpful comments made by one anonymous referee and by Dr David Nixon are much appreciated. 


\section{REFERENGES}

Allen, R. G., Pereira, L. S., Raes, D. and Smith, M. (1998). Crop evapotranspiration: guidelines for computing crop water requirements. Food and Agricultural Organisation of the United Nations, Irrigation and Drainage Paper 56, Rome, Italy.

Batchelor, G. R., Soopramanien, G. C., Bell, J. P., Nayamuth, R. and Hodnett, M. G. (1990). Importance of irrigation regime, dripline placement and row spacing in the drip irrigation of sugarcane. Agricultural Water Management 17:75-94.

Bell, J. P., Wellings, S. R., Hodnett, M. G. and Ah Koon, P. D. (1990). Soil water status: a concept for characterising soil water conditions beneath a drip irrigated row crop. Agricultural Water Management 17:171187.

Bull, T. and Glasziou, K. T. (1976). Sugar cane. In Crop Physiology, 51-72 (Ed. L. T. Evans). Cambridge: Cambridge University Press.

Carr, M. K. V. (2001). The water relations and irrigation requirements of coffee. Experimental Agriculture 37:1-36.

Carr, M. K. V. (2009). The water relations and irrigation requirements of banana (MUSA spp.). Experimental Agriculture 45:333-371.

Chabot, R., Bouarfa, S., Zimmer, D., Chaumont, C. and Moreau, S. (2005). Evaluation of the sap flow determined with a heat balance method to measure the transpiration of a sugarcane canopy. Agricultural Water Management $75: 10-24$.

Chang, Jen-hu, Campbell, R. B. and Robinson, F. E. (1963). On the relationship between water and sugar cane yield in Hawaii. Agronomy fournal 55:450-453.

Cowan, I. R. and Innes, R. F. (1956). Meteorology, evaporation and the water requirements of sugar cane. Proceedings of the International Society of Sugar-cane Technologists 9:215-232.

Dart, I. L., Baille, C. P. and Thorburn, P. J. (2000). Assessing nitrogen application rates for subsurface trickle irrigated sugarcane at Bundaberg. Procceedings of Australian Society of Sugarcane Technologists Conference. (Ed. D. M. Hogarth) 22:230-235.

Dodsworth, G. H., Nixon, D. J. and Sweet, C. P. M. (1990). An assessment of drip irrigation of sugarcane on poorly structured soils in Swaziland. Agricultural Water Management 17:325-335.

Donaldson, R. A. and Bezuidenhout, C. N. (2000). Determining the maximum drying off periods for sugarcane grown in different regions of the South African industry. Proceedings of the South African Sugar Technologists Association $74: 162-166$.

Doorenbos, J. and Kassam, A. H. (1979). Yield response to water. Food and Agricultural Organization of the United Nations, Irrigation and Drainage Paper 33, Rome, Italy.

Ellis, R. D. and Lankford, B. A. (1990).The tolerance of sugarcane to water stress during the main development phases. Agricultural Water Management 17:117-128.

Ellis, R. D., Wilson, J. H. and Spies, P. M. (1985). Development of an irrigation policy to optimise sugar production during seasons of water shortage. Proceedings of the South African Sugar Technologists Association 59:142-147.

FAO (2009). http://faostat.fao.org/site/339/default.aspx

Finkel, H. J. (1983). Irrigation of sugar crops. In CRC Handbook of Irrigation Technology, Volume II (Ed. H. J. Finkel), Florida, USA, CRC Press.

George, B. R. F (1988). A simple field method of scheduling irrigation. Proceedings of the South African Sugar Technologists Association 149-151.

Glover, J. (1967). The simultaneous production of sugar cane roots and tops in relation to soil and climate. Proceedings of the South African Sugar Technology Association 41:143-159.

Green, G., Sunding, D., Zilberman, D., and Parker, D. (1996). Explaining irrigation technology choices: a microparameter approach. American fournal of Agricultural Economics 78:1064-1072.

Gregory, P.J. (1990). Soil physics and irrigation: tapping the potential for drip. Agricultural Water Management 17:159-169.

Haines, M. G., Inman-Bamber, N. G., Attard, S. J. and Linedale, A. I. (2010). Enhancing irrigation management planning with EnviroScan and WaterSense. http://www.irrigation.org.au/assets/pages/762A58E3-1708-51EBA69E09D5747B3C06/82\%20-\%20Haines\%20Paper.pdf [Accessed 24 October 2010].

Hobhouse, H. (1985). Seeds of Change: Five Plants that Transformed Mankind. London: Sidgwick and Jackson Ltd.

Hodnett, M. G., Bell, J. P., Al Koon, P. D. Soopramanten, G. C. and Batchelor, C. M. (1990). The control of drip irrigation of sugarcane using 'index' tensiometers, some comparisons with control by the water budget method. Agricultural Water Management 17:180-207. 
Holden, J. R. (1998). Irrigation of Sugarcane. Bureau of Sugar Experiment Stations, Brisbane, Australia.

Humbert, R. P. (1968). The Growing of Sugar Cane. Amsterdam: Elsevier.

ICSM (International Consortium for Sugarcane Modelling). (2008). http://sasri.sasa.org.za/misc/ DSSAT\%20Canegro\%20SCIENTIFIC\%20documentation_20081215.pdf [Accessed 24 October 2010].

Inman-Bamber, N. G. (1994). Temperature and seasonal effects on canopy development and light interception of sugarcane. Field Crops Research 36:41-51.

Inman-Bamber, N. G. (1995). Automatic plant extension measurement in sugarcane in relation to temperature and soil moisture. Field Crops Research 42:135-142.

Inman-Bamber, N. G. (2004). Sugarcane water stress criteria for irrigation and drying off. Field Crops Research 89:107122.

Inman-Bamber, N. G., Attard, S. J., Haines, M. G. and Linedale, A. I. (2008). Deficit irrigation in sugarcane using the WaterSence scheduling tool. In Share the Water, Share the Benefits. Proceedings of the Irrigation Australia Congress, Melbourne, May 2008. http://www.irrigation.org.au/assets/pages/762A58E3-1708-51EBA69E09D5747B3C06/79\%20Inman\%20Paper2.pdf [Accessed 24 October 2010].

Inman-Bamber, N. G., Bonnett, G. D., Spillman, M. F., Hewitt, M. L. and Xu, J. (2009). Source-sink differences in genotypes and water regimes influencing sucrose accumulation in sugarcane stalks. Crop and Pasture Science 60:316-327.

Inman-Bamber, N. G. and De Jager, J. M. (1986). The reaction of two varieties of sugarcane to water stress. Field Crops Research 14:15-28.

Inman-Bamber, N. G. and McGlinchey, M. G. (2003). Crop coefficients and water-use estimates for sugarcane based on long-term Bowen ratio energy balance measurements. Field Crops Research 83:125-138.

Inman-Bamber, N. G., Muchow, R. C. and Robertson, M. J. (2002). Dry matter partitioning of sugarcane in Australia and South Africa. Field Crops Research 76:71-84.

Inman-Bamber, N. G., Schuurs, M. and Muchow, R. C. (1999). Advances in the science and economics of supplementary irrigation of sugarcane. Proceedings of the South African Sugar Technologists Association 73:9-15.

Inman-Bamber, N. G. and Smith, D. M. (2005). Water relations in sugarcane and response to water deficits. Field Crops Research 92:185-202.

Inman-Bamber, N. G. and Spillman, N. F. (2002). Plant extension, soil water extraction and water stress in sugarcane. Proceedings of the Australian Society of Sugar Cane Technologists 24:242-256.

James, G. (Ed.) (2004). Sugarcane. (2nd Edition). Oxford: Blackwell Publishing.

Jones, G. A., Santo, L. T., Kingston, G. and Gascho, G. J. (1990). Sugarcane. In Irrigation of Agricultural Crops (Eds. B. A. Stewart and D. R. Nielsen). Agronomy No. 30, Wisconsin, USA, American Society of Agronomy.

Julien, M. H. R., Irvine, J. E. and Benda, G. T. A. (1989). Sugarcane anatomy, morphology and physiology. In Diseases of Sugarcane (Eds. C. Ricaud, B. T. Egan, A. G. Gillaspie Jr. and C. G. Hughes). Amsterdam: Elsevier.

Kay, M. G. (1990). Recent developments for improving water management in surface and overhead irrigation. Agricultural Water Management 17:7-22.

Knox, J. W., Rodríguez Díaz, J. A., Nixon, D., and Mkhwanazi, M. (2010). A preliminary assessment of climate change impacts on sugarcane in Swaziland. Agricultural Systems 103:63-72.

Koehler, P. H., Moore, P. H., Jones, C. A., Dela Cruz, A. and Maretzki, A. (1982). Response of drip-irrigated sugarcane to drought stress. Agronomy fournal 74:906-911.

Laclau, P. B. and Laclau, J-P. (2009). Growth of the whole root system for a plant crop of sugarcane under rainfed and irrigated conditions in Brazil. Field Crops Research 114:351-360.

Lisson, S. N., Inman-Bamber, N. G., Robertson, M.J. and Keating, B. A. (2005). The historical and future contribution of crop physiology and modelling research to sugarcane production systems. Field Crops Research 92:321-335.

Liu, D. L., Kingston, G. and Bull, T. A. (1998). A new technique for determining the thermal parameters of phenological development in sugarcane, including suboptimum and supra-optimum temperature regimes. Agricultural and Forest Meteorology 90:119-139.

Martin, E. C., Stephens, W., Wiedenfeld, R., Bittenbender, H. C., Beasley, J. P. jr, Neibling, H., Gallian, J. J. and Moore, J. M. (2007). Sugar, Oil and Fibre. In Irrigation of Agricultural Crops (Eds R. J. Lascano and R. E. Sojka) Wisconsin: American Society of Agronomy.

Meinzer, F. C. and Grantz, D. A. (1989). Stomatal control of transpiration from a developing sugarcane canopy. Plant, Cell and Environment 12:635-642.

Merry, R. E. (2003). Dripping with success: the challenges of an irrigation redevelopment project. Irrigation and Drainage 52: 71-83. 
Meyer, W. S. (1997). The irrigation experience from Australia. In Intensive Sugarcane Production (Eds B. A. Keating and J. R. Wilson), 437-454, Wallingford, UK: CAB International.

Mhlanga, B. F. N., Ndlovub, L. S. and Senzanje, A. (2006). Impacts of irrigation return flows on the quality of the receiving waters: A case of sugarcane irrigated fields at the Royal Swaziland Sugar Corporation (RSSC) in the Mbuluzi River Basin (Swaziland). Physics and Chemistry of the Earth 31:804-813.

Ng Kee Kwong, K. F., Paul, J. P. and Deville, J. (1999). Drip fertigation - a means for reducing fertiliser nitrogen to sugarcane. Experimental Agriculture 35:31-37.

Nixon, D. J. and Workman, M. (1987). Drip irrigation of sugarcane on a poorly draining saline/sodic soil. In Proceedings of the South African Sugar Technologists Association, 140-145.

Olivier, F. and Singels, A. (2004). Survey of irrigation scheduling practices in the South African sugar industry. Proceedings of the South African Sugar Technologists Association 78:239-243.

Omary, M. and Izuno, F. T. (1995). Evaluation of sugarcane evapotranspiration from water table data in the Everglades agricultural area. Agricultural Water Management 27:309-319.

Pollok, J. G., Geldard, G. W. and Street, C. P. M. (1990). Experience with approximately 600 hectare drip irrigation at Simunye sugar estate, Swaziland. Agricultural Water Management 17:151-158.

Portmann, F., Siebert, S., Bauer, C. and Döll, P. (2008). Global dataset of monthly growing areas of 26 irrigated crops: version 1.0. Frankfurt Hydrology Paper 6, Institute of Physical Geography, University of Frankfurt (Main), Germany.

Purseglove, J. W. (1972). Tropical Crops: Monocotyledons. London: Longman.

Qureshi, M. E. Wegener, M. K., Harrison, S. R. and Bristow, K. L. (2001). Economic evaluation of alternative irrigation systems for sugarcane in the Burdekin delta in north Queensland, Australia. In Water Resources Management, 47-57 (Eds C. A. Brebbia, P. Anagnostopoulos, K. Katsifarakis and A. H-D. Cheng), Boston: WIT Press.

Roberts, J. M., Nayamuth, R. A., Batchelor, C. H. and Sooprramaten, G. C. (1990). Plant-water relations of sugarcane (Saccharum officinarum L.) under a range of irrigated treatments. Agricultural Water Management 17:95-115.

Robertson, M. J. and Donaldson, R. A. (1998). Changes in the components of cane and sucrose yield in response to drying-off of sugarcane before harvest. Field Crops Research 55:201-208.

Robertson, M. J., Inman-Bamber, N. G. and Muchow, R. C. (1997). Opportunities for improving the use of limited water by the sugarcane crop. In Intensive Sugarcane Production, 287-304, (Eds B. A. Keating and J. R. Wilson) Wallingford, UK: CAB International.

Robertson, M. J., Inman-Bamber, N. G., Muchow, R. C. and Wood, A. W. (1999). Physiology and productivity of sugarcane with early and mid-season water deficit. Field Crops Research 64:211-227.

Robertson, M. J., Wood, A. W. and Muchow, R. C. (1996). Growth of sugar cane under high input conditions in tropical Australia. I. Radiation use, biomass accumulation and partitioning. Field Crops Research 48:1 1-25.

SASA (1977). Irrigation of Sugarcane. Bulletin 17 (revised). The Experiment Station of the South African Sugar Association, Mount Edgecombe.

Simmonds, N. W. (1998). Tropical crops and their improvement. In Agriculture in the Tropics. 3rd edition. (Eds C. C. Webster and P. N. Wilson). Oxford: Blackwell Science.

Singels, A. and Smith, M. T. (2006). Provision of irrigation scheduling advice to small-scale sugarcane farmers using a web-based crop model and cellular technology: a South African case study. Irrigation and Drainage 55:363372.

Singels, A., van den Berg, M., Smit, M. A., Jones, M. R. and van Antwerpen, R. (2010). Modelling water uptake, growth and sucrose accumulation of sugarcane subjected to water stress. Field Crops Research 117:59-69.

Smit, M. A. and Singels, A. (2006). The response of sugar cane canopy development to water stress. Field Crops Research 98:91-97.

Smith, D. M., Inman-Bamber, N. G. and Thorburn, P. J. (2005). Growth and function of the sugarcane root system. Field Crops Research 92:169-183.

Soopramanien, G. C. and Batchelor, C. R. (Eds) (1987). MSIRI-IH Drip Irrigation Research Project: Second Ratoon Crop Interim Report. Mauritius Sugar Industry Research Institute, Reduit, Mauritius.

Sumner, M. E. (1997). Opportunities for amelioration of soil physical and chemical constraints under intensive cropping. In Intensive Sugarcane Production, 305-326, (Eds B. A. Keating and J. R. Wilson), Wallingford, UK: CAB International.

Teeluck, M. (1997). Development of the centre pivot irrigation system in Mauritius. http://www.gov.mu/portal/ sites/ncb/moa/farc/amas97/html/p02.htm [Accessed 24 October 2010].

Thompson, G. D. (1976). Water use by sugarcane. Review paper No. 8. The South African Sugar Fournal 60:593-600, $627-635$ 
Thompson, G. D. and Boyce, J. P. (1967). Daily measurements of potential evapotranspiration from fully canopied sugarcane. Agricultural Meteorology 4:267-279.

Thompson, G. D. and Boyce, J. P. (1971). Comparisons of measured evapotranspiration of sugarcane from large and small lysimeters. Proceedings of the South African Sugar Technologists Association 45:169-176.

Thompson, G. D. and Boyce, J. P. (1972). Estimating water use by sugarcane from meteorological and crop parameters. Proceedings of the International Society of Sugar Cane Technologists 14:813-826.

Thompson, G. D. and De Robillard, P. J. M. (1968). Water duty experiments with sugarcane on two soils in Natal. Experimental Agriculture 4:295-310.

Thompson, G. D., Gosnell, J. M. and de Robillard, P. J. M. (1967). Resposes of sugarcane to supplementary irrigation on two soils in Natal. Experimental Agriculture 3:223-238.

Thompson, G. D., Pearson, G. H. O. and Cleasby, T. G (1963). The estimation of the water requirements of sugarcane in Natal. Proceedings of the South African Sugar Technologists Association 37:134-141.

Tilley, L. and Chapman, L. (1999). Benchmarking crop water index for the Queensland sugar industry. Bureau of Sugar Experiment Stations, Brisbane, Australia.

Torres, J. S. (1998). A simple visual aid for sugarcane irrigation scheduling. Agricultural Water Management 38:77-83.

Turner, N. C. (1990). Plant water relations and irrigation management. Agricultural Water Management 17:59-73.

Van Antwerpen, R. (1999). Sugar cane root growth and relationships to above ground biomass. Proceedings of the South African Sugar Technologists Association 73:89-95.

Venkataramana, S., Gururaja Rao, P. N. and Naidu, K. M. (1986). The effects of water stress during the formative phase on stomatal resistance and leaf water potential and its relationship with yield in ten sugarcane varieties. Field Crops Research 13:345-353.

Wiedenfeld, R. P. (2000). Water stress during different sugarcane growth periods on yield and responses to N fertilisation. Agricultural Water Management 43:173-182.

Wiedenfeld, R. P. (2004). Scheduling water application on drip irrigated sugarcane. Agricultural Water Management 64:169-181.

Wood, G. H. and Wood, R. A. (1967). The estimation of cane root development and distribution using radiophosphorous. Proceedings of the South African Sugar Technology Association 41:160-168.

Yates, R. A. (1984). Sugar-cane as an irrigated crop. In Sugar Cane (Ed. F. Blackburn), Longman.

Yates, R. A. and Taylor, R. D. (1986). Water use efficiencies in relation to sugarcane yields. Soil Use and Management 2:70-76.

Zadrazil, H. (1990). Drag-line irrigation. Practical experience with sugarcane. Agricultural Water Management 17:25-35. 